POLITICS AND INTERNATIONAL RELATIONS

\title{
Deep Trade Agreements and Domestic Institutions in the Americas
}

\author{
Laura Gómez-Mera and Gonzalo Varela² \\ 1 University of Miami, US \\ 2 World Bank, US \\ Corresponding author: Laura Gómez-Mera (Igmera@miami.edu)
}

Preferential trade agreements (PTAs) have spread rapidly around the world since the 1990s. In the Americas, the proliferation of trade agreements with countries from within and beyond the region have resulted in a "spaghetti bowl" of overlapping rules and regulations, some of which address behind-the-border issues such as investment, competition, labor, and environmental standards. Earlier research has linked trade agreements to increased foreign investment inflows. This article argues instead that the effects of PTAs on FDI depend on the domestic institutional capacities of member countries. Domestic institutions condition the benefits and effectiveness of PTAs by influencing governments' external credibility as well as their ability to implement the agreements they sign. The empirical findings show that weak state capacity exacerbates the spaghetti-bowl effects of multiple, overlapping agreements. Moreover, it is not the quantity but the quality, and more specifically, the depth of trade agreements that matters for attracting FDI.

Los acuerdos de libre comercio se han propagado rápidamente por el mundo a partir de los años noventa. En las Américas, la proliferación de acuerdos comerciales con países dentro y fuera de la región ha resultado en un 'spaghetti bowl' de reglas y regulaciones paralelas y que se superponen. En este trabajo, argumentamos que el efecto de los acuerdos preferenciales de comercio (APC) sobre la IED depende de la calidad de las instituciones nacionales en los países miembros. Las instituciones políticas de cada país miembro afectan la credibilidad externa, así también como su capacidad para implementar los acuerdos que firman, de esa forma condicionando los beneficios y la efectividad de los APC. De acuerdo con nuestro análisis empírico, la baja capacidad estatal exacerba efectos negativos del 'spaghetti bowl' comercial. Además, la calidad (o profundidad) de los APC importa más que la cantidad. Los acuerdos comerciales profundos, que abarcan temas y regulaciones domésticos, tienden a atraer mayores flujos de IED que los acuerdos superficiales.

Since the 1990s, preferential trade agreements (PTAs) have spread rapidly and widely throughout the world. At the time of writing, a total of 635 such agreements have been notified to the World Trade Organization (WTO), of which 267 are currently in force. Countries in Latin America and the Caribbean (LAC) have been active in the trading system, accounting for 25 percent of all agreements in force. Indeed, the proliferation of PTAs in the Americas has resulted in an intricate network of overlapping rules, some of which go beyond trade to address behind-the-border issues such as investment, competition policy, and the environment. Increasingly, this so-called spaghetti bowl of agreements has grown to include ties with extraregional partners.

Regional integration has a long and convoluted history in the Americas. Despite the limited success of various waves of regionalism in fueling intraregional trade interdependence, ${ }^{2}$ Latin American governments

\footnotetext{
${ }^{1}$ When considering also Canada and the United States, countries in the Americas are members in 90 (33 percent) of the total 267 agreements currently in force.

2 The share of intraregional exports (to total exports) for countries in LAC remained almost unchanged (at 20 percent) between 2003 and 2014 and was slightly lower than in 1992. Intraregional trade flows accounted for 50 percent of total trade in East Asia Pacific, and for 60 percent of total European trade (Bown et al. 2017).
} 
never seem to get tired of signing new, sometimes ambitious, agreements. ${ }^{3}$ Recently, regional integration seems to have returned to the "forefront of the policy debate" in LAC (Bown et al. 2017). In addition to seeking an expansion in intraregional trade, this more recent strategy of deeper-that is, covering behindthe-border issues-PTAs aims to promote global integration by expanding exports and investment ties with third countries. Indeed, FDI attraction has been an important motivation for LAC countries to negotiate and sign PTAs with developed country partners, such as the United States and the European Union, despite the important domestic regulatory adjustments they have entailed. ${ }^{4}$ As Baldwin $(2011,3)$ claims, twenty-firstcentury trade agreements must be viewed as an exchange of "foreign factories for domestic reforms."

Has this strategy of pursuing broader and deeper trade integration paid off for LAC countries? We address this question by examining the extent to which signing more, and deeper PTAs has helped attract FDI into the region-one of the stated objectives of this strategy. Inflows of FDI into Latin America have also grown over the past fifteen years, with the region accounting for over 11.3 percent of world inflows in 2018 (UNCTAD 2019). To what extent has this increase been associated with the growing participation of countries in the region in trade agreements? Given its active participation in trade agreements, and its importance as a destination for FDI flows, Latin America and the Caribbean seems particularly suited to explore these questions empirically.

We argue that the effects of the number and content of trade agreements on foreign investment depends on the quality of domestic institutions. In particular, we are interested in the role of state capacity, understood as the ability of institutions to effectively implement a basic set of core functions and effectively enforce laws (Luna and Soifer 2015), in mediating the potential benefits of trade integration for LAC countries. We identify two mechanisms-limited implementation and eroded credibility-through which poor state capacity undermines the effectiveness of trade agreements in attracting FDI. Our empirical findings, based on statistical analysis of the trade integration and FDI patterns for countries in LAC between 2001 and 2015, support these claims. In countries where the government is effective in formulating and implementing policies and in the delivery of public goods and enforcement of regulations, deeper trade agreements are associated with higher FDI inflows. By contrast, weak institutional and technical capacities appear to offset the investment attraction benefits of deep agreements. Indeed, poor domestic governance seems to exacerbate the spaghetti-bowl effect of multiple overlapping agreements (Bhagwati 1995). By providing empirical evidence highlighting the conditions under which PTAs are more likely to work for LAC countries, this article makes a novel contribution to the vast literature on regional integration and trade agreements in the Americas and beyond.

\section{Regionalism in the Americas}

Regional integration has long been a favored strategy of Latin American and Caribbean governments. In the 1950s and 1960s, economic integration sought to complement national policies of import substitution (Devlin and Ffrench-Davis 1998). In the late 1980s and 1990s, in contrast, a new wave of "open regionalism" ensued. The strategy of regional trade liberalization, pursued in tandem with unilateral and multilateral opening, succeeded in increasing intraregional interdependence among LAC countries. However, poor implementation and limited political commitment to regional institutions once again undermined integration, fueling talk about the exhaustion and "peaking" of regionalism in Latin America (Gómez-Mera 2013; Malamud and Gardini 2012). Nevertheless, new "post-neoliberal" regional initiatives, such as the Venezuela-led Bolivarian Alliance for the Americas (ALBA) and the South American Union (UNASUR), came to be in the 2000s (Riggirozzi 2017). Unlike their 1990s predecessors, these regional cooperation initiatives advanced a more state-centric development strategy, seeking to promote regional cooperation in social, political, and security issues.

The early 2000s witnessed another important change in the landscape of regional cooperation in the Western Hemisphere. The collapse of the US-led attempts to establish a Free Trade Area of the Americas in 2005 led to a shift in the northern hegemon's trade policy toward the region. Instead of seeking hemispheric cooperation, the US launched a strategy of bilateral preferential agreements, which offered market access in exchange of a series of commitments and disciplines on domestic regulatory issues. Deep bilateral free trade

\footnotetext{
3 On the "implementation gap" and "capabilities-expectations-gap" in Latin American regionalism, see Jenne, Schenoni, and Urdinez (2017).

${ }^{4}$ For example, in its assessment of the potential benefits from the free trade agreement with the US, Colombia's Banco de la Republica stressed the expectation of higher FDI inflows as one of the main projected benefits (Toro et al. 2006). Similarly, the Panamanian Ministry of Trade and Industry expressed hopes that the trade agreement with the US, would result in an expansion of FDI in services sectors, particularly logistics and financial (Ministerio de Comercio e Industrias 2012).
} 
agreements soon became the cornerstone of the US strategy of "competitive liberalization" (Solís, Stallings, and Katada 2009). Between 2004 and 2007, the US concluded agreements with Chile, Central America and the Dominican Republic, Colombia, Ecuador, Peru, and the Caribbean countries. Bilateral agreements also began to be favored by LAC countries. Indeed, the mid-2000s witnessed not just an expansion in the web of bilateral links between countries in Latin America, but also an increase in the number of PTAs with extraregional partners. This expansion also included negotiations between regional trade blocs, such as the agreements signed in 2008 between the European Union and the Caribbean Community (CARICOM) and between the Mercado Común del Sur (MERCOSUR) and the South African Customs Union. As a result of this intense activity, as Figure 1 shows, after 2003, there was a marked increase in the number of PTAs signed by countries in the Americas. Moreover, some countries, like Chile, Peru, and Mexico, have been more active than others in signing bilateral agreements with countries from within and beyond the Western Hemisphere (Figure 2). ${ }^{5}$

An important feature of this more recent wave of trade agreements is their coverage of a wide range of border and behind-the-border regulatory issues (Chauffour and Kleimann 2012). Some of the policy areas covered in these agreements, such as trade facilitation, technical standards, and public procurement, fall under the current mandate of the WTO and are already subject to some form of commitment there-so-called WTO-plus agreements (Horn, Mavroidis, and Sapir 2010; Orefice and Rocha 2014). Others, such as labor standards, human rights, competition policy, intellectual property rights, and investment measures, are not covered in the current multilateral rules, and hence tend to be referred to as "WTO-extra (X)" issues. Table A1 in the online appendix, which compares the main agreements in the region in terms of their coverage, shows that PTAs signed with developed countries, namely the United States and the European Union, tend to include a larger number of WTO-X issues. At the same time, however, agreements among Latin American countries, and between them and other developing countries, have also increased in their depth since the early 2000s. A good example of this deepening in PTAs is the renegotiation and updating in 2018 of the 2006 agreement between Chile and China. Apart from revised rules on market access, trade in services, and rules of origin, the revamped agreement also contains new chapters on trade and the environment, as well as digital trade. ${ }^{6}$

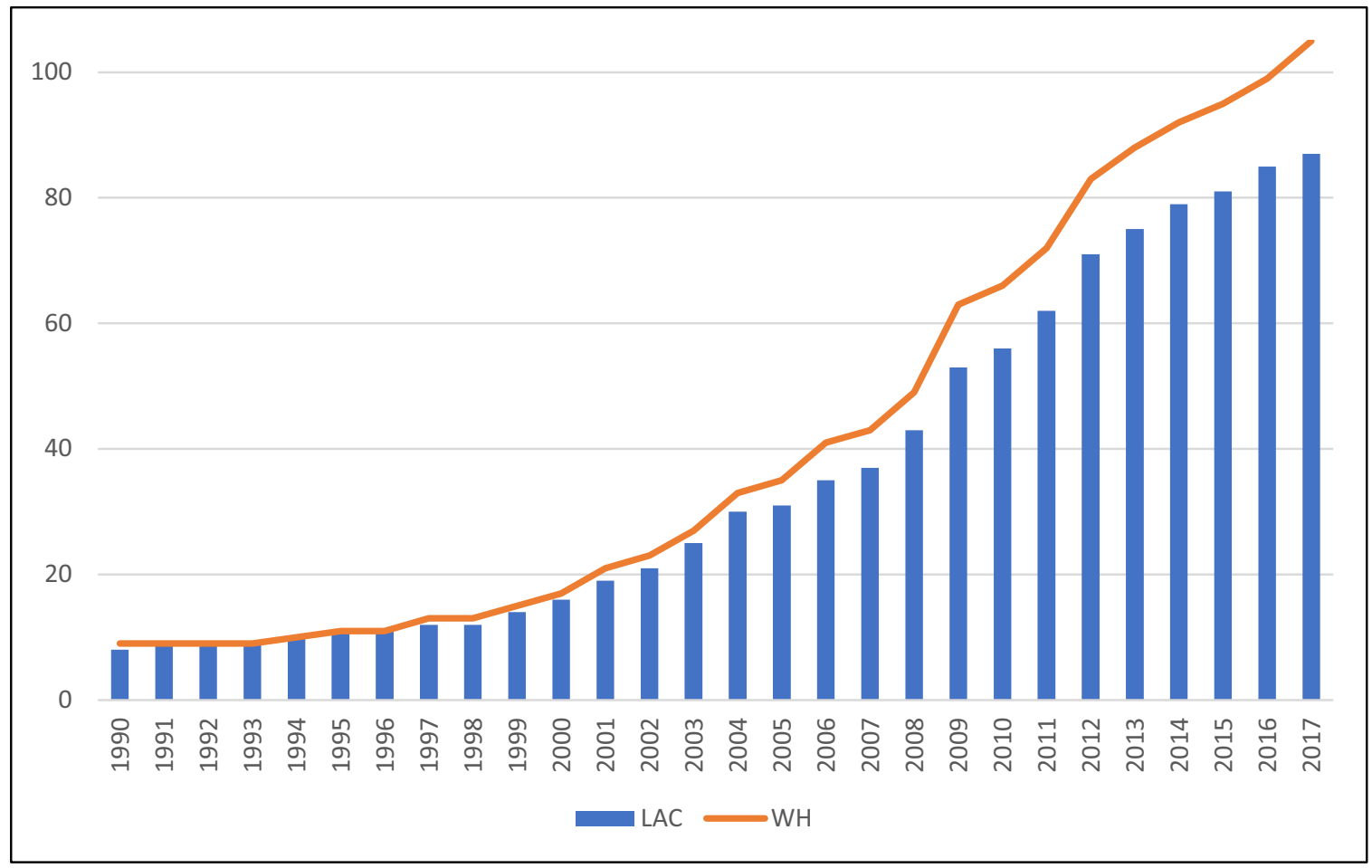

Figure 1: Cumulative number of PTAs signed by countries in the Americas. $\mathrm{WH}=$ Western Hemisphere countries, that is, LAC plus Canada and United States. Number of agreements in force by year.

\footnotetext{
${ }^{5}$ In contrast, MERCOSUR members are constrained from signing agreements individually by the Common Market Council Decision 32/00 - the "FTA-clause." On the debate concerning the actual implications of this clause, see Urdinez, López-Burian, and Oliveira (2016); Arnold (2017).

${ }^{6}$ See, e.g., "Chile estrecha lazos con su mayor socio comercial: Senado aprobó la modernización del TLC con China," Publimetro, October 26, 2018.
} 


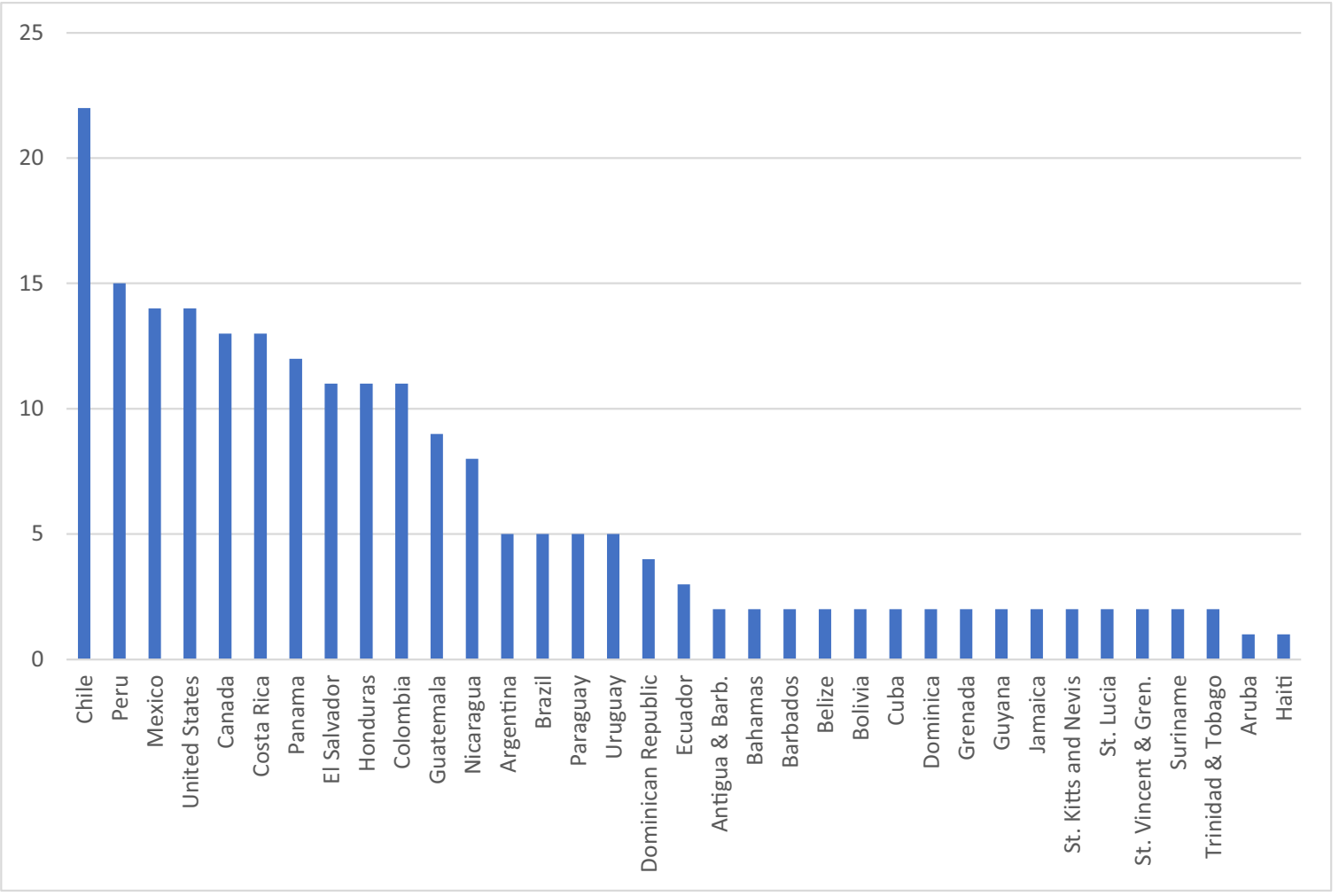

Figure 2: Cumulative number of PTAs by country (2017). Number of agreements in force at the end of 2017.

According to Bown et al. (2017), this new push toward deeper regional integration has been partly inspired by the success of this strategy in East Asia. Over the past three decades, East Asian economies have not only impressively increased the density of their intraregional trade ties but have also expanded exports to the rest of the world and their participation in global value chains. These trends have coincided with an increase in income levels for East Asian countries, fueling beliefs in Latin America that strengthening economic links within (and beyond) the region may lead to faster growth (Bown et al. 2017).

To what extent have LAC countries benefited from the increase in the number and depth of PTAs observed in the past two decades? In the remainder of this article, we examine whether this more active strategy of preferential trade integration helped countries in the Americas attract more FDI.

\section{Theoretical Framework and Hypotheses \\ PTAs and their benefits}

To address our central question, namely, the extent to which LAC countries benefit from participation in multiple and sometimes overlapping trade agreements, we draw on the economics and international political economy literatures on the expected benefits of PTAs. PTAs liberalize trade among members, providing them with preferential access to their respective markets while also discriminating against nonmembers. In evaluating their welfare implications, economists traditionally focused on the balance between their "trade creation" and their "trade diversion" effects (Viner 1950). Yet this early analysis has been adapted to recognize the various dynamic effects that PTAs may have in a globalized economy.

Economists, for example, have also considered the various mechanisms through which preferential trade liberalization could work to increase FDI inflows, thus enhancing attractiveness of PTAs to developing countries. First, by creating an extended common market, PTAs may attract firms from non-member countries that want to take advantage of export opportunities (Medvedev 2012). ${ }^{7}$ Second, by reducing the cost of trading and thus facilitating the exchange of intermediate and finished products among parent firms and their foreign subsidiaries, PTAs are expected to promote vertical FDI among members (Ethier 2001; Levy Yeyati, Stein, and Daude 2003)..$^{8}$ Along these lines, Vallejo and Aguilar (2002) found that the North American Free Trade Agreement (NAFTA), the Andean Community, and the Central American Common Market (CACM) contributed to an increase in intraregional FDI inflows.

\footnotetext{
${ }^{7}$ See Feils and Rahman (2008) for evidence of how NAFTA and DR-CAFTA, respectively, have worked to attract FDI from third countries.

${ }^{8}$ By the same token, PTAs are associated with decreased incentives for horizontal or "tariff-jumping" FDI (Markusen 1984; Caves 1996).
} 
Finally, economists and political scientists have emphasized the political economy mechanisms through which PTAs may work to attract foreign investment. In particular, PTAs may act as "commitment mechanisms" that signal policy transparency and predictability and thus contribute to mitigating the so-called time-inconsistency problem inherent in foreign investment (Büthe and Milner 2008, 2014). Indeed, once an investment is made, a rational government faces incentives to breach the terms of the agreement, expropriate assets, or introduce regulatory changes that make the investment less profitable for the firm. Firms will anticipate this type of opportunistic behavior and will be discouraged from investing in certain countries unless they can be given some guarantees. ${ }^{9}$ An extensive body of literature has looked at the role of bilateral investment treaties (BITs) in helping states solve this credibility problem. BITs specify several guarantees to foreign investors, most notably, the possibility of seeking third-party arbitration in international tribunals, while signaling commitment to market friendly policies. Yet, membership in other types of international organizations and agreements can also work to signal and strengthen governments' policy credibility (Dreher, Mikosch, and Voigt 2015). Thus, Büthe and Milner (2008) argue that by joining PTAs, and other trade institutions like the General Agreement on Trade and Tariffs and the World Trade Organization (WTO), developing countries show their commitment not just to the reduction of tariffs and other barriers to trade but more generally to liberal economic policies.

This commitment enhancing effect is reinforced in the case of recent PTAs, which contain provisions on domestic regulatory issues. Many of these deep agreements include specific investment provisions, such as for example, commitment to the removal of barriers to international capital flows and relaxation of restrictions on foreign ownership and participation, which are expected to result in higher FDI inflows. Similarly, provisions on intellectual property, competition policy, and standards harmonization may also attract more investment by improving countries' investment climate (Medvedev 2012). Along these lines, several studies have found a positive effect on FDI inflows not just of the presence and the number of PTAs but also of their depth (e.g., Büthe and Milner 2008; Orefice and Rocha 2014; Osnago, Rocha, and Ruta 2015).

Yet some studies have emphasized the potentially negative consequences of the coexistence of multiple, overlapping trade agreements. The so-called spaghetti-bowl effect refers to the complications and increased costs resulting from diverging rules of origin in overlapping PTAs. The trade agreement signed between the United States and the countries in Central America (DR-CAFTA), according to Granados and Cornejo (2006), illustrates these difficulties. This agreement brought together three preexisting agreements, namely, the Central American Common Market, the agreement between the five CACM countries and the Dominican Republic, and the free trade agreement between the US and these six countries. Despite similarities among the three arrangements, they differed in important ways, such as their rules of origin regimes. Once DR-CAFTA was established, the overlaps between the new multilateral regime of origin and the preexisting ones introduced fragmentation, increasing transaction costs for private and public actors (Granados and Cornejo 2006). According to Bown et al. (2017, 137), in fact, "the increasing number of FTAs, and the complex network of rules of origin that arises from that increase, can accentuate the uncertainty faced by firms seeking to invest in foreign countries and can deter foreign direct investment into a country." In line with these studies, a report by the Dominican Ministry of Industry and Trade assessing the impact of DR-CAFTA claimed that the agreement has had only a "moderate" effect of FDI inflows because "its implementation has been challenging for the Dominican industrial sector" (Villanueva and Polanco 2010, 6).

\section{The intervening role of state capacity}

PTAs have several potential economic effects for the countries that join them. Not only do they promote trade among members; they may also attract FDI. Yet trade agreements, and especially deeper ones, also pose important challenges for governments, particularly in developing countries. While the literature reviewed recognizes the problems associated with multiple, overlapping agreements, little attention has been paid to the importance of state capacity and domestic institutions in conditioning the impact of these agreements. On the one hand, state capacity conditions the ability of governments to negotiate and conclude trade agreements, thus influencing the number and nature of agreements that a country will belong to. But at the same time, extensive administrative, regulatory, and technical capacities are required not only for the negotiation but also for the implementation of trade agreements (Chauffour and Kleimann 2012). As Walls, Smith, and Drahos $(2015,2)$ put it, "The capacity needed is expensive, skill-intensive, and requires considerable infrastructure, which smaller and poorer states especially struggle to find." ${ }^{10}$

\footnotetext{
${ }^{9}$ Vernon (1971) refers to this problem as the "obsolescing bargain" in FDI.

${ }^{10}$ Rollo (2007) refers to the disadvantages that developing countries face when negotiating trade agreements, given that "human capital is often the binding constraint."
} 
Institutional capacity demands are heightened in the context of overlapping trade agreements. First, the simultaneous negotiation of multiple agreements requires extensive technical capacity and coordination across the different venues. For countries in LAC, the proliferation of PTAs with different countries within and beyond the Western Hemisphere increased the number of summits and meetings that public officials must attend, thus putting additional strain on national budgets (Malamud and Giardini 2012; Mace, Thérien, and Tussie 2015). The broader scope of many of these arrangements also called for engagement of multiple ministries and governmental agencies and their coordination among themselves and with other economic actors, including business groups and unions (Heidrich and Tussie 2009). In addition, as countries become members of several agreements that differ in their sectoral coverage, liberalization schedules, and rules of origins, the challenges associated with their implementation increase not only for private actors but also for public officials in charge of enforcing them, as the example of DR-CAFTA discussed above illustrates (Estevadeordal and Suominen 2009).

Indeed, for LAC countries, the administrative and technical costs of compliance and implementation grew dramatically with the signing of more comprehensive agreements with the US and other developed countries (González 2009). These North-South agreements, which tend to reflect the preferences of industrialized partners, present complex implementation challenges, placing heavy burdens on developing countries (Deere 2005). While shallow agreements require relatively simple trade policy changes-for example, the reduction or elimination of tariffs-the more recent agreements involve substantive domestic regulatory and institutional reforms. Chauffour, González, and Maur (2011) identify several implementation challenges of deep integration agreements, all of which underscore the importance of governments' institutional and regulatory capacities. First, deep PTAs may call for institutional changes, including the reorganization and/or creation of new agencies. In 2008, for example, a Ministry of Environment was created in Peru to meet the requirements of the US-Peru PTA (Bastiaens and Postnikov 2017). Second, some provisions, such as those concerning intellectual property rights and the environment, require the drafting of new domestic laws and regulations. In Central America, for example, Nicaragua and Costa Rica both amended domestic intellectual property laws to comply with DR-CAFTA (Biadgleng and Maur 2011). Finally, these institutional and regulatory reforms entail important administrative and procedural changes, including training of staff, interagency coordination, and establishment of monitoring mechanisms.

According to Chauffour and Kleimann $(2012,49)$, the severe institutional and regulatory capacity constraints of developing countries constitute "the single most important obstacle to PTA implementation." In line with this, we argue that by constraining the implementation of PTAs, poor regulatory and institutional capacities of states, undermine the ability of LAC countries to gain from deep trade agreements. Our analysis of the benefits of deep integration for Latin America and the Caribbean seeks to shed light on the intervening role of state capacity, understood as the ability of institutions to effectively implement a basic set of core functions and effectively enforce laws (Luna and Soifer 2015).

An extensive literature in international relations has linked state capacity with implementation and effectiveness of international agreements (Chayes and Chayes 1993; Guzman 2002; Cole 2016). In contrast, the scholarship on PTAs has paid limited attention to the ways in which the administrative and institutional capacities of the state may affect a country's ability to implement and hence benefit from these agreements. An exception is Gray (2014), who argues that the "implementation gap" that characterizes many regional trade organizations in the developing world is explained by problems of state capacity. ${ }^{11}$ Gray (2014) concentrates on the ways in which weak domestic legal environment and inadequate infrastructure hinder compliance and implementation and result in lower levels of trade interdependence. Relying on expert survey data, her work shows a strong correlation between the quality of domestic infrastructure and rule of law and the ability of regional arrangements to promote trade.

Like Gray $(2014,60)$, we believe that without sufficient domestic capacity, "the promise of international agreements may not always be fulfilled." Specifically, we argue that by making compliance and implementation harder, weak state capacity also conditions the extent to which developing countries can reap the benefits of preferential trade liberalization. While Gray focuses on the effectiveness of trade agreements in promoting trade, we consider another expected their role in attracting investment by multinational firms.

There are two mechanisms through which state capacity may influence the potential of PTAs in promoting trade and FDI among member countries. First, and in line with Gray, we view state capacity undermining PTA effectiveness through its impact on implementation. In other words, by constraining compliance and

11 Another exception is Goltermann (2012). Scholars have also looked at the ways in which deep integration affects state capacity. For example, Bruszt and Campos (2016) focus on Europe. 
implementation, weak state capacity and government effectiveness erodes the expected commercial benefits of PTAs. The inability of governments to stick to liberalization commitments and to implement harmonized rules and regulations will neutralize the ability of PTAs to promote intrapartnership trade. But in addition, weak compliance and implementation will increase other non-trade-related costs of transactions for firms operating in global value chains, creating incentives to shift production and investment to other markets. A second alternative mechanism is particularly relevant when considering the ability of PTAs to attract FDI. Inadequate rule of law and regulatory quality undermine the signaling and commitment enhancement effects of PTAs stressed by Büthe and Milner (2008) and other international political economy scholars. As Gray (2014, 61) notes, "the implementation of international agreements requires that contracts of all types be enforced on the ground. Upholding the rule of law is another prerequisite for maintaining credible commitments."

Along these lines, we hypothesize that a country's state capacity affects its ability to benefit from trade agreements. We thus expect state capacity to significantly condition the effects of both the number and the depth of trade agreements that countries sign on FDI inflows:

$\mathbf{H}_{\mathbf{1}}$ : The higher a country's state capacity, the stronger the association between the number of trade agreements it signs and FDI inflows.

$\mathbf{H}_{2}$ : The higher a country's state capacity, the stronger the association between the depth of its trade agreements and FDI inflows.

\section{Empirical Analysis Data and variables}

To test these hypotheses, we compiled a data set on patterns of FDI and PTA membership for a sample of twenty-nine countries in LAC for the period 2001-2015. During this period, all countries in our sample have participated in at least one preferential trade agreement that has been notified to the WTO. The unit of analysis is the country-year and we use a fixed effect estimator, which allows us to control for any country time-invariant unobservable that may affect FDI and be correlated with agreement adherence and state capacity. We also include year effects to control for common shocks affecting all countries in the sample, such as global liquidity, or across-the-board liberalization trends. We estimate the following model:

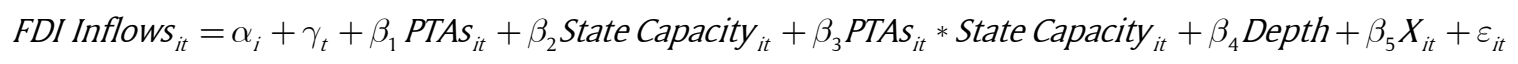

The dependent variable $\left(F D I_{i t}\right)$ is the net $F D I$ inflows into a given country in a given year, measured in millions of current US dollars. Data for this variable is from the UNCTAD database on FDI flows. There are three main independent variables of interest. The first two capture the effects of the number and depth of trade agreements. First, PTAs is the cumulative number of preferential trade agreements (in force) to which a country belongs at the end of a given year. ${ }^{12}$ In constructing this variable, we use data from the WTO's regional trade agreement database. We include not only full-scope free trade agreements (FTAs) such as NAFTA but also partial-scope arrangements, like the Latin American Integration Association (ALADI). In addition, we include agreements signed with countries in other regions. The value of PTAs varies significantly across countries and years in our sample. In 2015, for example, the cumulative number of PTAs ranged from 1 for Aruba to 23 for Chile. In addition, the cumulative number of PTAs in force has grown rapidly in recent years, as shown by Figure 1.

Second, to measure the depth and scope of trade agreements, we use an index constructed by Hofmann, Osnago, and Ruta (2018) that aggregates the number of provisions in PTAs signed by each country. Drawing on Horn, Mavroidis, and Sapir (2010), this index identifies a set of policy areas covered in trade agreements, which can be classified according to whether they fall under the current mandate of the WTO ("WTO-plus") or whether they are outside its reach ("WTO-extra"). Of the fifty-two types of provisions identified, fourteen are classified as WTO-plus and thirty-eight are WTO-extra. Aggregate depth thus varies from 1 to 52 . We use this to calculate the average annual Depth of integration for each country in our sample. That is, for each country $I$ in year $t$, Depth $_{i t}$ is the average of the total depth of all the agreements it belongs to in that particular year. As Figure A1 in the appendix shows, average depth for the countries in our sample varies from 15 for Bolivia and Ecuador to 30 for Haiti. ${ }^{13}$

\footnotetext{
${ }^{12}$ We thus do not consider PTAs that have not been notified to the WTO. We also include only those agreements that are currently in force.

${ }^{13}$ The high depth for countries in the Caribbean reflects the broad coverage of CARICOM (thirty provisions) and the almost-asbroad scope (twenty-seven) of the EU-CARICOM agreement signed in 2008.
} 
Our other main variable of interest is State Capacity of of the host country $i$ in year $t$. Significant debate has surrounded the conceptualization and operationalization of this term. Here, we follow Mann's (1984, 189) understanding of state capacity as the ability of the state "to implement logistically political decisions through the realm." Moreover, like Cárdenas (2010), we understand state capacity to include not only aspects of bureaucratic efficiency but also the state's ability to raise revenue from society, to deliver basic public goods, and to provide a sound legal and institutional framework that protects property rights. We thus use three indicators drawn from the World Bank's World Governance Indicators (WGI), which seek to capture "the capacity of the government to effectively formulate and implement sound policies" (Kaufmann, Kraay, and Mastruzzi 2010, 4). Government effectiveness measures the quality of public services, the quality and independence of the civil service, and the quality and credibility of policy formulation and implementation. Rule of law captures another aspect of state capacity, namely, the "quality of contract enforcement, property rights, the police, and the courts, as well as the likelihood of crime and violence" (Kaufman, Kraay, and Mastruzzi 2010, 4). Finally, Regulatory quality measures the ability of the government to formulate and implement sound policies and regulations that promote private sector development. The three indices take measures of -2.5 to 2.5, with higher values indicating stronger performance. Even though they are not without criticism,${ }^{14}$ these indicators capture important dimensions of the regulatory and administrative capacities that, as discussed in the previous section, are crucial for the implementation of trade agreements. While the Rule of law variable measures the institutional features that we associate with the signaling mechanism, the other two variables could be viewed as more relevant to testing the implementation channel through which state capacity may condition the effectiveness of PTAs.

Our hypotheses concern the interactive effect of PTAs and state capacity on FDI inflows. We predict that the greater a country's state capacity, the more likely it will be to implement its PTAs, or to signal credibility to investors, and hence the greater the FDI flows it will attract. To test these claims, we interact PTAs and Depth with each of the indicators of state capacity (in separate models, due to high correlation among them). We expect the coefficient of these interaction terms to be positive. We then consider the effect of Depth in trade agreements and its interaction with state capacity indicators.

In addition, we control for three factors that affect FDI inflows and are also associated with the number of agreements a country signs and with the level of state capacity, namely, level of economic development, measured as the log of the country's per capita gross domestic product (GDP; in current US dollars) and market size, measured as the log of population, and the member country's level of trade openness, measured as the log of the sum of its imports and exports of goods and services as a percentage of GDP. Data for these variables comes from the World Bank's World Development Indicators.

The main empirical challenge in this research design is the possibility of endogeneity. Endogeneity may arise because of reverse causality, as an increase in FDI inflows might make countries more likely to sign PTAs. For example, a country that is host to multinational firms may face pressures to engage in preferential trade relations to expand the market opportunities and thus reduce trading costs of these investors. Similarly, it could be argued that higher FDI inflows contribute to building domestic institutional capacity. One way to deal with this problem is to rely on an instrumental variable approach. However, to the best of our knowledge, the literature has not identified convincing instruments for PTA formation, that is, satisfying both the relevance restriction (that the instrument be correlated with the causal variable-PTAs in this case) and the exclusion restriction (that the instrument is uncorrelated with any other determinants of FDI). To mitigate endogeneity concerns, we examine the lagged effects of PTAs and state capacity on FDI. By lagging the PTA variables - number and depth of PTAs-we substantially reduce the scope for endogeneity, while also allowing a time-adjustment for agents to become aware of PTAs and make their investment decisions. $^{15}$

Another endogeneity concern lies in the existence of omitted variables that may be correlated both with PTA formation and with FDI attraction. In this respect, we follow Medvedev $(2012,53)$ in assuming that the use of panel data with fixed effects "adequately addresses the endogeneity problem as long as the unobservables determining the likelihood of forming a PTA are not time-dependent." Year dummies also help reduce the scope of omitted variables that may vary over time and affect all countries alike, such

\footnotetext{
${ }^{14}$ For a response to and a summary of some of the criticisms, see Kaufmann, Kraay, and Mastruzzi (2007).

${ }^{15}$ We lag these variables two years, thus examining whether signing an agreement in time $t$ increases FDI flows in $t+2$. It is worth mentioning that our strategy of using PTA lags to tackle the endogeneity problem assumes no anticipation effect, by which potential investors lobby for PTAs to be signed two or more years prior to the actual investment. While it is likely that investors do anticipate and lobby in advance to some extent, the generous time-choice for lags reduces the scope for these concerns.
} 
as technological change reducing transport costs or improving information technology connectivity that increases FDI and the propensity of countries to sign PTAs. ${ }^{16}$

\section{Results}

Table 1 contains the results of our main regression analysis. We begin by estimating the individual effects of PTAs on FDI inflows using country and year fixed effects. The models in this table use the two-year lag of the annual count of PTAs, that is, we examine whether the number of PTAs a country belonged to in year $t-2$ is associated with the level of foreign investment inflows in $t$. In model 1 , the estimated coefficient for

Table 1: Number of PTAs, state capacity, and FDI inflows: Fixed effects models.

\begin{tabular}{|c|c|c|c|c|c|c|}
\hline & $\begin{array}{l}\text { (1) } \\
\mathrm{FE}\end{array}$ & $\begin{array}{l}\text { (2) } \\
\mathrm{FE}\end{array}$ & $\begin{array}{l}\text { (3) } \\
\mathrm{FE}\end{array}$ & $\begin{array}{c}(4) \\
\text { GMM }\end{array}$ & $\begin{array}{c}\text { (5) } \\
\text { GMM }\end{array}$ & $\begin{array}{c}(6) \\
\text { GMM }\end{array}$ \\
\hline \multirow[t]{2}{*}{ L.FDI Inflows (log) } & & & $0.267^{* * *}$ & $0.200^{* * *}$ & $0.243^{* * *}$ & $0.259^{* * *}$ \\
\hline & & & $(0.0629)$ & -0.041 & -0.048 & -0.052 \\
\hline \multirow[t]{2}{*}{ (Log)Population } & $3.060^{* *}$ & $4.136^{* * *}$ & $2.381^{*}$ & 3.041 & 2.678 & 2.605 \\
\hline & -1.522 & -1.481 & $(1.256)$ & -2.314 & -2.288 & -2.654 \\
\hline \multirow[t]{2}{*}{ (Log)GDP per capita } & $1.710^{* * *}$ & $1.565^{* *}$ & $1.074^{*}$ & 1.370 & 1.346 & $1.511^{*}$ \\
\hline & -0.615 & -0.607 & $(0.586)$ & -0.938 & -0.901 & -0.865 \\
\hline \multirow[t]{2}{*}{ (Log)Trade/GDP } & 0.183 & 0.297 & $0.420^{* *}$ & $0.311^{*}$ & 0.309 & 0.199 \\
\hline & -0.195 & -0.209 & (0.193) & -0.186 & -0.197 & -0.192 \\
\hline \multirow[t]{2}{*}{ Depth } & $0.085^{* * *}$ & $0.127^{* * *}$ & $0.126^{* * *}$ & $0.124^{* * *}$ & $0.106^{* *}$ & $0.0803^{*}$ \\
\hline & -0.026 & -0.036 & $(0.0328)$ & -0.048 & -0.049 & -0.044 \\
\hline \multirow[t]{2}{*}{ L.PTAs } & -0.020 & $-0.0709^{* *}$ & $-0.0758^{* * *}$ & $-0.0761^{* *}$ & -0.072 & -0.071 \\
\hline & -0.023 & -0.033 & $(0.0262)$ & -0.036 & -0.046 & -0.063 \\
\hline \multirow[t]{2}{*}{ L.Rule of law } & & $0.821^{* * *}$ & 0.310 & 0.422 & & \\
\hline & & -0.291 & $(0.293)$ & -0.296 & & \\
\hline \multirow[t]{2}{*}{ L.PTAs $\times$ Rule of law } & & $0.0448^{* *}$ & $0.0546^{* * *}$ & $0.0515^{* *}$ & & \\
\hline & & -0.020 & $(0.0155)$ & -0.023 & & \\
\hline \multirow[t]{2}{*}{ L.Gov. effectiveness } & & & & & -0.296 & \\
\hline & & & & & -0.247 & \\
\hline \multirow[t]{2}{*}{ L.PTAs $\times$ Gov. effectiveness } & & & & & 0.054 & \\
\hline & & & & & -0.034 & \\
\hline \multirow[t]{2}{*}{ L. Reg. quality } & & & & & & -0.317 \\
\hline & & & & & & -0.248 \\
\hline \multirow[t]{2}{*}{ L.PTAs $\times$ Reg. quality } & & & & & & 0.042 \\
\hline & & & & & & -0.043 \\
\hline Observations & 414 & 414 & 400 & 357 & 357 & 357 \\
\hline $\mathrm{R}^{2}$ & 0.980 & 0.981 & 0.986 & & & \\
\hline Hansen test & & & & 1.00 & 1.00 & 1.00 \\
\hline Difference-in-Hansen tests & & & & 1.00 & 1.00 & 1.00 \\
\hline
\end{tabular}

${ }^{16}$ Another potential methodological concern is associated with the fact that our two main independent variables-the number of PTAs and state capacity-may also vary together. This however, does not really add to endogeneity concerns because our research design controls for the fact that state capacity may directly and indirectly affect FDI flows. Moreover, we include both trade agreements and state capacity as independent variables. So, if trade agreements depend on state capacity, then that portion of the effect on FDI is captured already by state capacity, and the effect of the agreement on FDI is purged of the effect of state capacity. 
PTAs is negative but statistically insignificant. By contrast, the estimated coefficient for Depth is positive and statistically significant at the 1 percent level, suggesting that while the net effect of the number of trade agreements signed by a country does not significantly affect the level of FDI inflows, the depth of these agreements does.

We then explore our first hypothesis, namely, whether the ability of countries to benefit from the PTAs they sign depends on the quality of their institutions. In model 2, the coefficient for PTAs $\times$ Rule of law is positive and statistically significant, in line with our expectations. However, the coefficient for the individual effect of PTAs, which maintains its negative sign, now becomes statistically significant. ${ }^{17}$ We obtain similar results in models 3 when adding a two-year lag of the dependent variable (log of FDI inflows). However, a problem with this specification is that the lagged dependent variable is endogenous to the fixed effects in the error term, giving rise to dynamic panel bias (Roodman 2006). To overcome this, in models 4-6, we use the Blundell-Bond estimator. ${ }^{18}$ In model 4, the estimated coefficient for PTAs $\times$ Rule of law is significantly positive, while the individual effect of PTAs remains significant and negative. Models 4 and 5 replace Rule of law with Government effectiveness and Regulatory quality, respectively, and while the interactive terms are positive, they are slightly below conventional levels of statistical significance.

These results are in line with $\mathrm{H}_{1}$, namely, that the effect of the cumulative number of PTAs is conditional on the quality of members' domestic institutions. They show, first, that signing more trade agreements does not necessarily translate into higher FDI inflows and may even decrease them. This is consistent with PTAs having a spaghetti-bowl effect by which the trade diversion effects offsets the expected trade creation effects for the signatory country and make investors indifferent about investing in the country. Yet while signing multiple agreements may work to deter FDI inflows, this negative effect is at least partially offset in the context of high performing domestic institutions. However, the fact that only the interaction of PTAs with Rule of law is statistically significant may suggest that the stability of business regulations and the effectiveness of government agencies are not as relevant as the strength of the rule of law in mediating the effects of trade agreements on FDI.

Figure 3 shows how the marginal effect of PTAs varies across observed levels of Rule of law-in other words, how the predicted impact of an additional PTA on FDI inflows increases with the rule of law score in the host country. For countries with very poor-quality rule of law, signing another agreement has a statistically

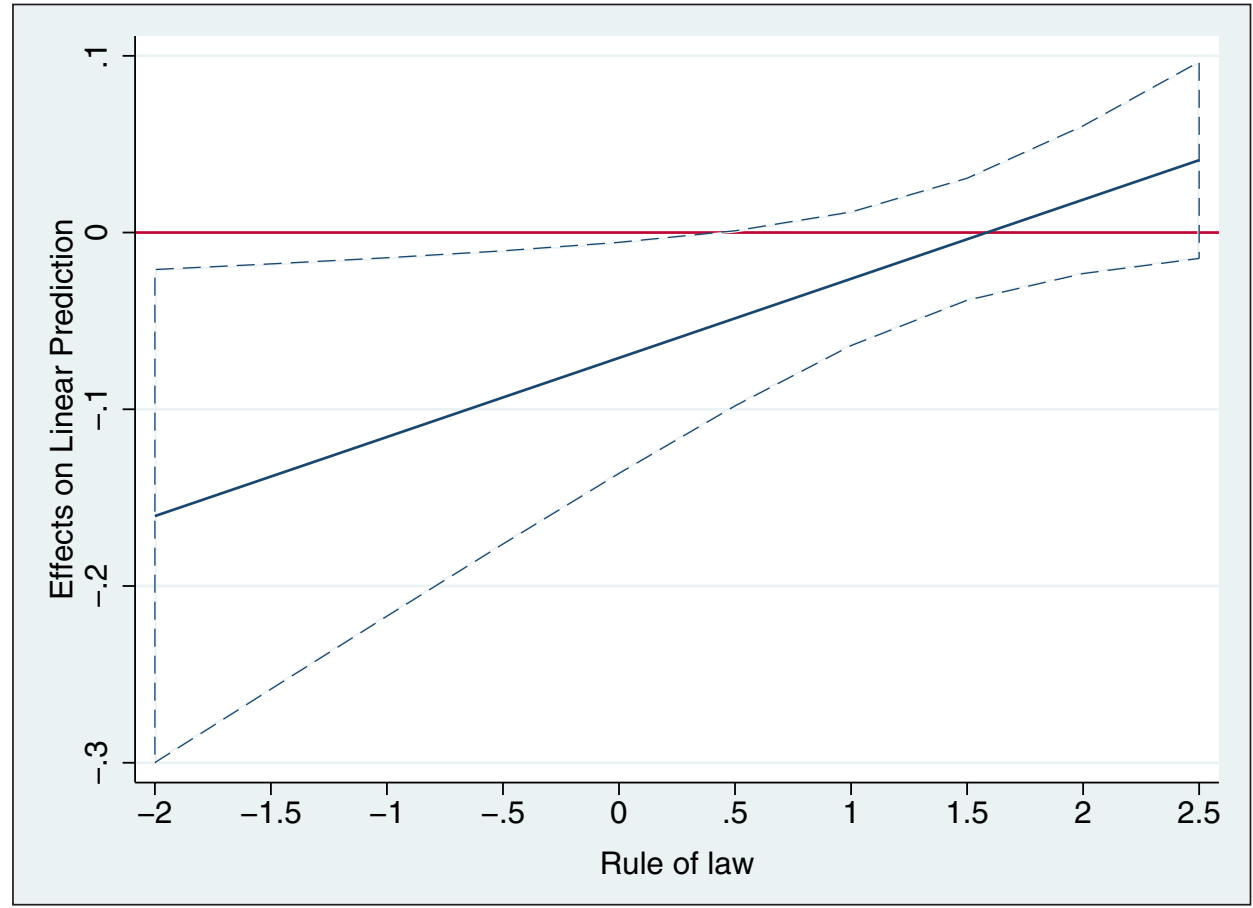

Figure 3: Average marginal effect of number of PTAs conditional on rule of law. Based on model 2, Table 1 $(95 \% \mathrm{CI})$.

${ }^{17}$ When using Government effectiveness or Regulatory quality instead of Rule of law, the estimated coefficients for the interactive effects are positive but not statistically significant.

${ }^{18}$ The Blundell and Bond (1998) estimator is a system GMM estimator that extends Arellano and bond (1991). It deals with the endogeneity of the lagged dependent variable by instrumenting it with its own lags. 
significant negative effect on FDI. However, as rule of law improves this negative impact becomes smaller. In other words, the quality of domestic institutions somewhat mitigates the spaghetti-bowl effect of multiple agreements. Indeed, at values of Rule of law approximating 2, the marginal effect turns positive, although it is not statistically significant.

More agreements are therefore not necessarily a good thing for countries in the Americas. The results in Table 1, however, show a highly significant and positive estimated coefficient for Depth across specifications. All else equal, the deeper the agreements that a county belongs to, the higher the FDI inflows it attracts. Are these positive effects of depth also conditional on the level of state capacity and institutional quality of members? To test $\mathrm{H}_{2}$, in the models presented in Table 2, we interact our indicators of state capacity with Depth. Models 1 and 4 show that both Depth and Depth $\times$ Rule of law have positive and statistically significant coefficients, even when controlling for past levels of FDI inflows (and using system generalized method-of-moments, or GMM, estimators). Moreover, the linear combination of these estimated coefficients,

Table 2: PTA depth, state capacity, and FDI: Fixed-effects models.

\begin{tabular}{|c|c|c|c|c|c|c|}
\hline & $\begin{array}{l}\text { (1) } \\
\mathrm{FE}\end{array}$ & $\begin{array}{l}\text { (2) } \\
\mathrm{FE}\end{array}$ & $\begin{array}{l}\text { (3) } \\
\mathrm{FE}\end{array}$ & $\begin{array}{c}(4) \\
\text { GMM }\end{array}$ & $\begin{array}{c}\text { (5) } \\
\text { GMM }\end{array}$ & $\begin{array}{c}\text { (6) } \\
\text { GMM }\end{array}$ \\
\hline \multirow[t]{2}{*}{ L.FDI Inflows (log) } & & & & $0.147^{* * *}$ & $0.196^{* * *}$ & $0.215^{* * *}$ \\
\hline & & & & $(0.0429)$ & $(0.0411)$ & $(0.0387)$ \\
\hline \multirow[t]{2}{*}{ (Log)Population } & $5.244^{* * *}$ & $5.193^{* * *}$ & $5.156^{* * *}$ & $3.102^{*}$ & 2.929 & 2.121 \\
\hline & $(1.785)$ & $(1.900)$ & $(1.920)$ & $(1.616)$ & $(1.957)$ & (1.724) \\
\hline \multirow[t]{2}{*}{ (Log)GDP per capita } & $2.469^{* * *}$ & $2.733^{* * *}$ & $2.593^{* * *}$ & $2.140^{* * *}$ & $2.277^{* * *}$ & $2.064^{* * *}$ \\
\hline & $(0.562)$ & $(0.579)$ & $(0.580)$ & $(0.553)$ & $(0.701)$ & $(0.673)$ \\
\hline \multirow[t]{2}{*}{ (Log)Trade/GDP } & -0.114 & -0.162 & -0.142 & -0.143 & -0.143 & -0.0924 \\
\hline & $(0.210)$ & $(0.217)$ & $(0.211)$ & $(0.218)$ & $(0.210)$ & $(0.228)$ \\
\hline \multirow[t]{2}{*}{ L.PTAs } & -0.0384 & -0.0296 & -0.0299 & -0.0149 & -0.00939 & -0.00706 \\
\hline & $(0.0248)$ & $(0.0252)$ & $(0.0253)$ & $(0.0188)$ & $(0.0214)$ & $(0.0212)$ \\
\hline \multirow[t]{2}{*}{ L.Depth } & $0.0903^{* * *}$ & $0.0948^{* * *}$ & $0.0593^{*}$ & 0.0654 & 0.0676 & 0.0317 \\
\hline & $(0.0296)$ & $(0.0308)$ & $(0.0321)$ & $(0.0407)$ & $(0.0472)$ & $(0.0451)$ \\
\hline \multirow[t]{2}{*}{ L.Rule of law } & -1.083 & & & -1.051 & & \\
\hline & $(0.803)$ & & & $(0.869)$ & & \\
\hline \multirow[t]{2}{*}{ L.Depth $\times$ Rule of law } & $0.0902^{* * *}$ & & & $0.0814^{* *}$ & & \\
\hline & $(0.0337)$ & & & -0.0349 & & \\
\hline \multirow[t]{2}{*}{ L.Gov. effectiveness } & & $-2.488^{* * *}$ & & & $-1.938^{*}$ & \\
\hline & & $(0.788)$ & & & (1.177) & \\
\hline \multirow[t]{2}{*}{ L.Depth $\times$ Gov. effectiveness } & & $0.0902^{* * *}$ & & & $0.0746 *$ & \\
\hline & & $(0.0291)$ & & & $(0.0429)$ & \\
\hline \multirow[t]{2}{*}{ L.Reg. quality } & & & -0.855 & & & -1.198 \\
\hline & & & $(0.733)$ & & & $(0.755)$ \\
\hline \multirow[t]{2}{*}{ L.Depth $\times$ Reg. quality } & & & 0.0397 & & & $0.0519 *$ \\
\hline & & & $(0.0282)$ & & & $(0.0275)$ \\
\hline Observations & 361 & 361 & 361 & 309 & 309 & 309 \\
\hline $\mathrm{R}^{2}$ & 0.985 & 0.984 & 0.984 & & & \\
\hline Hansen test & & & & 1.00 & 1.00 & 1.00 \\
\hline Difference-in-Hansen tests & & & & 1.00 & 1.00 & 1.00 \\
\hline
\end{tabular}

Note: All models include country and year fixed effects. Robust standard errors in parentheses. ${ }^{* * *} p<0.01 ;{ }^{* *} p<0.05 ;{ }^{*} p<0.1$. 
that is, the average marginal effect of Depth on FDI inflows, is also positive and statistically significant at the 1 percent level. All else equal, deeper integration increases FDI inflows, yet the magnitude of the effect depends on the quality of the rule of law in the host country. Similar findings are obtained when using Government effectiveness (models 2 and 5). The estimated coefficients for Depth and for the interaction terms with Government effectiveness are positive and statistically significant, even when the lagged dependent variable is not included in the model). Finally, the interaction of Depth and Regulatory quality is also positive and significant at the 10 percent level in the dynamic panel (model 6).

To shed further light on the conditional relationship between Depth and institutional capacity, we examine the estimated marginal effect of this variable over a range of meaningful values Government effectiveness. As Figure 4 shows, the conditional relationship is not significant over very low values of this indicator. For Government effectiveness greater than -0.5 , however, the marginal effect is positive and statistically significant. As the positive slope of the line shows, the higher the level of state capacity, the stronger the effect of Depth on FDI inflows. Similarly, Depth has a statistically significant effect on FDI inflows only for levels of Rule of law greater than 0 , and this effect grows in magnitude as values for Rule of law. ${ }^{19}$

Figure 5, in turn, shows the predicted FDI inflows at varying depths of integration for two medium-sized countries, such as for example Chile and Peru. Although both countries are similar in terms of GDP, which is sometimes used as an indicator of market size, Chile's state capacity indicators are higher than Peru's. For example, in 2014, the Rule of law score for Chile reached 1.43 while Peru's was -0.52. If Peru, which in 2014 had fourteen PTAs, were to expand its Depth score (the average depth of all its trade agreements) from 25 to 26 , it could expect to see FDI inflows increase by 0.2 percent. Instead, a country with Chile's much stronger rule of law institutions would derive much higher benefits from deepening integration. An increase in Depth from 22 to 23 is associated with an increase in predicted FDI inflows by a factor of 1.19 (i.e., 19 percent), all other factors being held constant.

In sum, the results in Tables $\mathbf{1}$ and $\mathbf{2}$ provide support for our central claim that the benefits of trade agreements are conditional on the quality of domestic institutions. The strength of the rule of law, the effectiveness of the government in formulating and implementing policies, and the quality of the regulatory

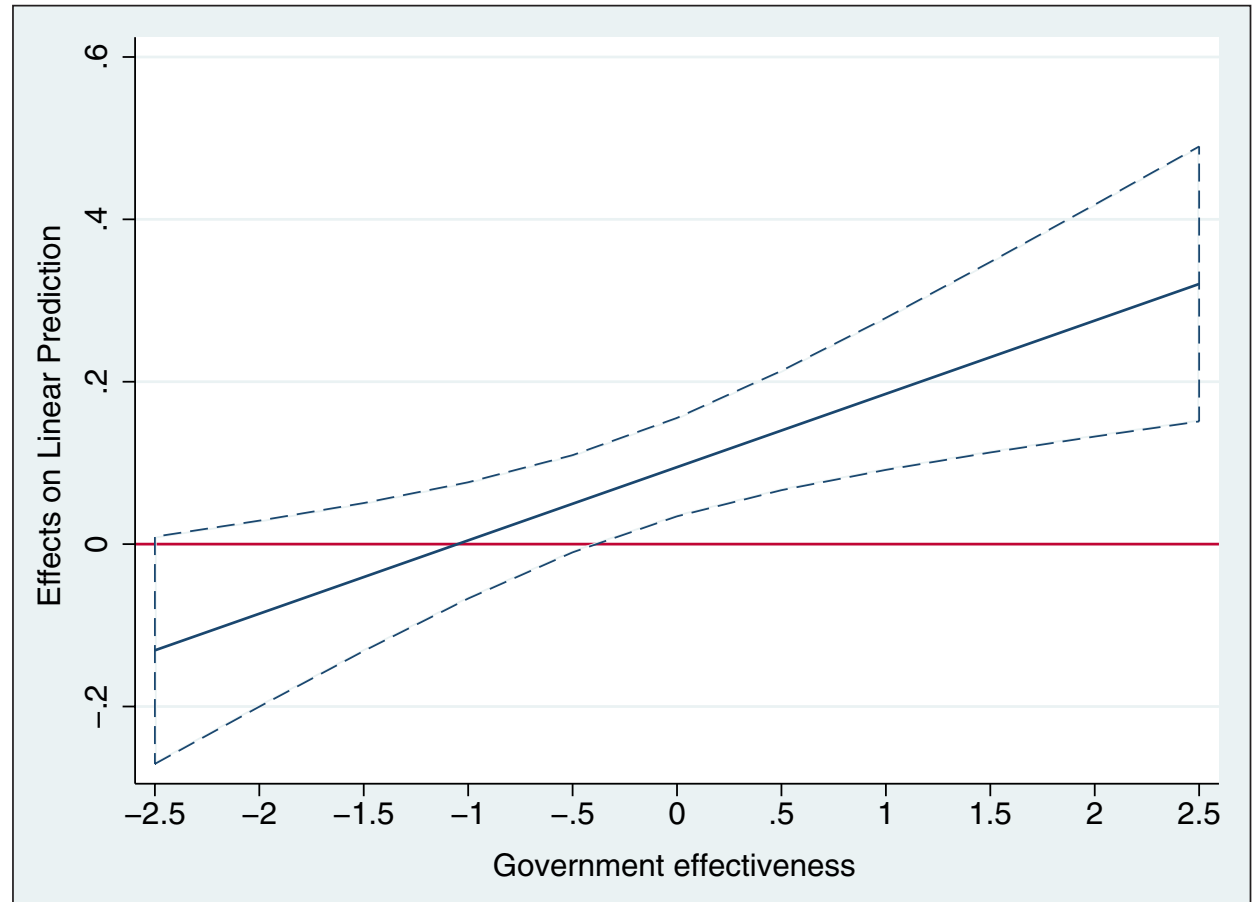

Figure 4: Average marginal effect of depth conditional on governmental effectiveness. Based on model 2, Table 2.

\footnotetext{
${ }^{19}$ Figures A1 and A2 in the appendix also illustrate the intervening role of state capacity in the Depth-FDI association, showing the predicted levels of FDI inflows for different levels of Government effectiveness and Rule of law. As the quality of domestic institutions increases, the lines become steeper, suggesting a stronger impact on FDI of a deepening in trade integration.
} 


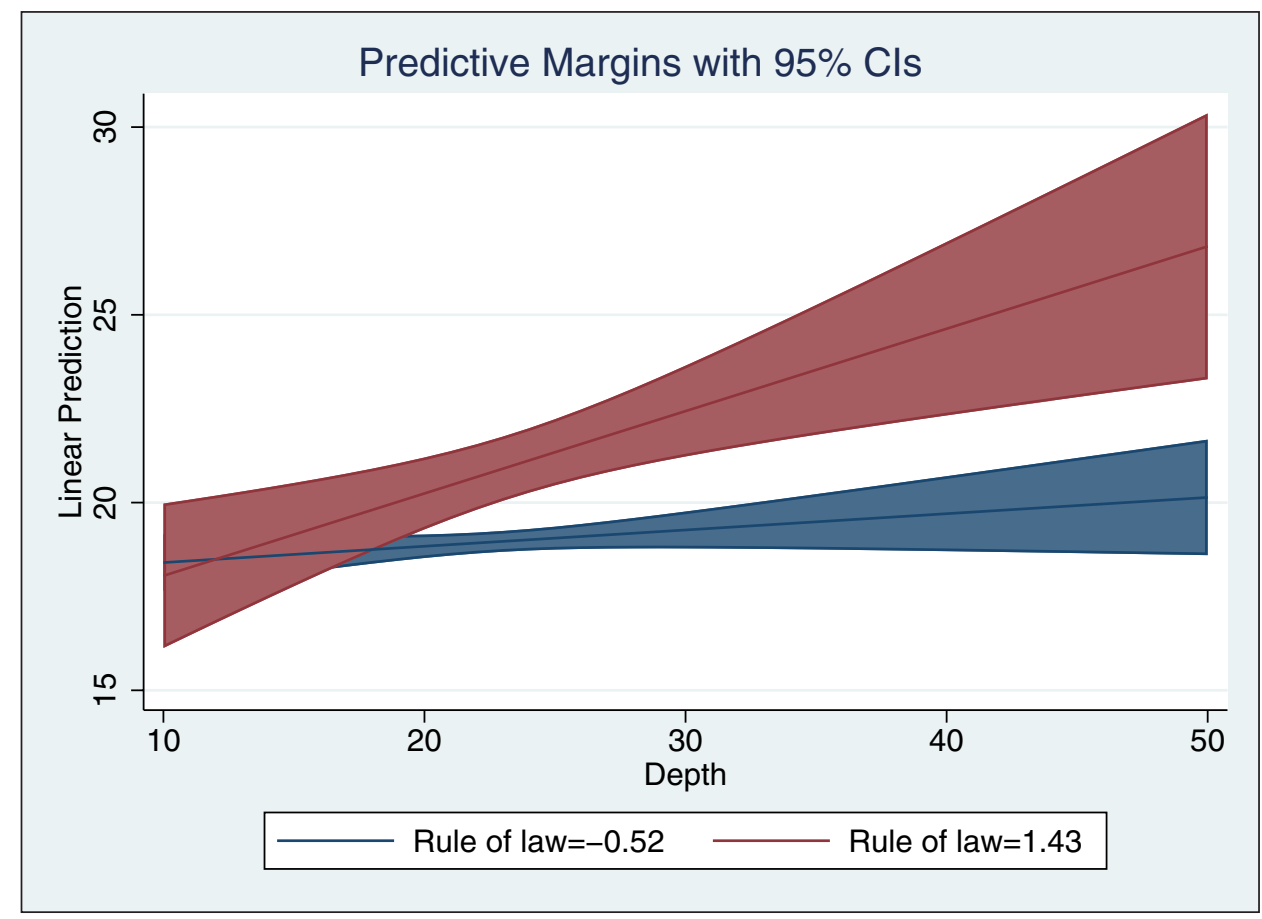

Figure 5: PTA depth and FDI inflows conditional on rule of law. Based on model 1, Table 2.

process, seem to condition the effects of both the number of PTAs signed and their depth on FDI levels. In particular, our findings give support to our claim that very poor levels of state capacity, by hindering implementation and credibility, undermine the effectiveness of PTAs in attracting FDI. Far from increasing their attractiveness to foreign investors, countries with very low state capacity may undermine it when signing more and deeper trade agreements.

\section{Robustness checks}

Our results are robust to alternative estimation techniques and different measures of the dependent and independent variables. We first estimate our baseline models using FDI as a percentage of GDP as the dependent variable (Table A3 in the online appendix). Although the estimated coefficient for the interaction of state capacity and the cumulative number of PTAs is positive, it is not statistically significant (model 1). However, we still find support for our second hypothesis, concerning the interaction of Depth and state capacity. The interactions of Depth and both Rule of law and Government effectiveness remain positive and statistically significant (models $2-5$ ). Results are unchanged when using the system GMM model and including the two-year lag of the dependent variable (FDI/GDP). These findings are to some extent consistent with our main findings, which suggest that depth has a clearer effect than quantity of agreements on FDI.

In an attempt to look at whether participation in PTAs and state capacity influence not just the amount but also the concentration of FDI, we run the model using the number of announced investment projects into each country as the dependent variable. ${ }^{20}$ The results show that while the number of PTAs does not significantly affect the count of investments announced for each country, the average depth of these agreements is negatively associated with it (Table A5). In other words, the deeper the PTAs a country belongs to, the fewer the investment projects that it attracts. The interaction of Depth and state capacity, however, fails to reach statistical significance. These results, while less robust than our central findings, suggest that deeper agreements may lead to higher but also more concentrated FDI inflows-that is, fewer but larger projects.

We then replace WGI indicators of state capacity with an indicator of Quality of government developed by Teorell et al. (2018) with data from International Country Risk Guide. ${ }^{21}$ The interaction of the number of PTAs

\footnotetext{
${ }^{20}$ Data for this robustness test comes from the FDI markets database, which compiles information on announcements of investment projects by multinational companies in different sectors of the economy. See https://www.fdimarkets.com.

${ }^{21}$ The Quality of government indicator is the mean value of ICRG measures of corruption, law and order, and bureaucratic quality, scaled 0 to 1 .
} 
and Quality of government indicator is positive and statistically significant, providing further support for our first hypothesis (Table A5). In line with $\mathrm{H}_{2}$, Depth $\times$ Quality of government is also statistically significant and has the expected sign. Similar results are obtained with the World Bank's Country Policy and Institutional Assessment indicator Quality of public administration..$^{22}$

The article's main findings are also robust to the exclusion of specific countries-Brazil, Argentina, Mexico, and Chile-and regional groupings. We find support for both $\mathrm{H}_{1}$ when excluding all the main trade blocs in the Americas, namely MERCOSUR, CAN, CACM, and CARICOM. However, our findings concerning the interaction of Depth of integration and state capacity appear to be sensitive to the exclusion of CARICOM countries (Table A6). Finally, we try including a different structure of lags for PTAs and Depth. The central findings remain largely unchanged when using the three- and the five-year lag of these two variables. However, when including a one-year lag and no lags, the estimated coefficients for the interaction terms of Depth and the state capacity indicators are not statistically significant, suggesting that depth of integration takes at least a couple of years to influence FDI (Table A7).

\section{Conclusions}

Regional integration is once again high on the economic policy-making agenda of countries in Latin America and the Caribbean. This strategy is of course not new; indeed, it has been attempted in a variety of forms since the 1960s. In its more recent incarnation, regional trade cooperation seeks to promote growth by fostering trade and investment ties with countries within and beyond the Western Hemisphere. Through broader and deeper trade integration, countries seek to attract foreign investment, expand exports, and achieve stable economic growth. This article has examined the extent to which this strategy of multiple and deeper trade agreements has contributed to these objectives. In particular, we are interested in whether and the extent to which domestic institutions mediate the impact of PTAs on FDI inflows.

Two main findings emerge from the analysis. First, it is not the quantity but the quality, and more specifically, the depth of the trade agreements that matters. Indeed, we find that for countries in the Americas in the period 2001-2015, a greater number of trade agreements is associated with lower FDI inflows. These results are consistent with spaghetti-bowl arguments, highlighting the problems associated with the overlap of multiple agreements. While against theoretical expectations (see, e.g., Büthe and Milner 2008), these findings resonate with recent public opinion data on the perceived benefits of integration. For example, according to a poll conducted by the Inter-American Development Bank's Institute for Integration in Latin America (INTAL) and the Latinobarómetro, those countries that have signed a higher number of trade agreements are the least supportive of free trade (negative $r=-0.49$ ). As Basco $(2017,30)$ puts it, it is "noteworthy" that the weakest support for free trade is noted in Pacific Alliance countries (72 percent of support on average), which signed the greatest number of PTAs. ${ }^{23}$

By contrast, our findings suggest all else equal-and controlling for the number of PTAs-depth is associated with higher investment inflows. The deeper the trade integration ties of a country, the more attractive it appears to be for investors. Deep agreements go beyond tariff reductions, with provisions that are often nondiscriminatory, and hence, have a "public good" aspect. For example, a pair of countries may sign a deep agreement that covers tariff liberalization, and in addition, customs reforms. The benefits of customs reforms will certainly accrue to both signatory countries in terms of improved trade, but also to any other country trading with them, since the resulting improved processes in customs will not be only applied on the shipments from signatory countries, but on all of them. Foreign direct investors will see this as a benefit of doing business in these countries and therefore will be more likely to invest there.

Second, the effects of both number and depth of trade agreements is significantly mediated by the quality of domestic institutions. Our analysis shows that state capacity conditions the extent to which a country benefits or not from trade agreements. High state capacity, for example, mitigates the observed negative spaghetti effect of signing multiple, overlapping PTAs. The weaker a country's rule of law and government effectiveness indicators, the more difficulties it will confront in trying to implement its various trade agreements. Anticipating this, foreign investors may be deterred from entering these markets. However, our analysis highlights a positive reinforcing interaction between depth of trade agreements and state capacity.

\footnotetext{
${ }^{22}$ We also tried the V-Dem project's fiscal capacity indicator as an alternative measure of our independent variable but obtained no statistically significant associations with the dependent variable. This may indicate that this particular aspect of state capacity, associated with revenue collection, is less relevant both for the implementation of agreements and in terms of signaling for investors.

${ }^{23}$ See "A más tratados, menos apoyo al libre comercio?," El Comercio, May 4, 2018.
} 
The stronger the rule of law and government effectiveness, the greater the effectiveness of deep PTAs in attracting FDI. While our methodological framework prevents us from properly testing them, we propose two potential mechanisms that may be at play. First, poor state capacity undermines the effectiveness of PTAs through its impact on implementation and compliance. Weak compliance and implementation will increase other costs of transactions for firms operating in global value chains-not necessarily related to trade, creating incentives to shift production and investment to other markets. Second, inadequate rule of law and may undermine the signaling and commitment enhancement effects of PTAs stressed international political economy scholars. Here we add to Büthe and Milner's (2008) claims about the greater credibility of international commitments relative to domestic policy choices. We show how weak state capacity undermines the credibility benefits of international agreements. More research is needed to explore and verify the validity of these potential causal connections, as well as to explore whether they are relevant when considering other potential benefits of trade agreements, such as for example, export and trade expansion.

Our findings point to the importance of domestic institutions, and in particular, the effectiveness of the state in formulating and implementing policies, as well as in enforcing laws and regulations, for regional integration. They suggest that, in the case of less developed countries, low capacity may hinder participation in regional and extraregional trade agreements, and more broadly in international production networks. Moreover, even when joining these arrangements, problems of capacity may prevent them from fully benefiting from participation. This analysis highlights the importance of state capacity in foreign policy in general and trade policy making in particular. ${ }^{24}$ Our analysis also has implications for discussions on the impact of the proliferation of PTAs and the increasing fragmentation of trade governance in the Americas. The growing number of overlapping agreements will benefit members as long as they have the technical resources and institutional capacities to implement them. Indeed, for countries with very low levels of state capacity, an additional PTA may reduce rather than increase foreign investment.

Our empirical analysis only covers LAC, making it hard to draw generalizations about the applicability of our findings to other regions. We hope that future research can build on the insights derived from this study to shed further light on the interaction of trade agreements and domestic institutions and their effects not only on FDI attraction but also more generally on participation in global value chains. While cross-national data on the distribution of investment flows is limited at this stage, further research will ideally seek to shed more light on the ways in which PTAs and domestic institutions interact to influence both the magnitude and the concentration of FDI.

\section{Additional Files}

The additional files for this article can be found as follows:

Online Appendix. Tables and figures. DOI: https://doi.org/10.25222/larr.679.s1

- Data File. Stata form. DOI: https://doi.org/10.25222/larr.679.s2

\section{Author Information}

Laura Gómez-Mera is associate professor of political science at the University of Miami. She is the author of Power and Regionalism in Latin America (2013).

Gonzalo Varela is senior economist at the World Bank. His research interests focus on international economics, and in particular on how trade and investment policy shape firms' performance. He holds a $\mathrm{PhD}$ in economics from the University of Sussex.

\section{References}

Amorim Neto, Octavio, and Andrés Malamud. 2019. "The Policy-Making Capacity of Foreign Ministries in Presidential Regimes: A Study of Argentina, Brazil, and Mexico, 1946-2015." Latin American Research Review 54 (4): 812-834. DOI: https://doi.org/10.25222/larr.273

Arellano, Manuel, and Stephen Bond. 1991. "Some Tests of Specification for Panel Data: Monte Carlo Evidence and an Application to Employment Equations." Review of Economic Studies 58 (2): 277-297. DOI: https://doi.org/10.2307/2297968

Arnold, Christian. 2017. "Empty Promises and Nonincorporation in Mercosur." International Interactions 43 (4): 643-667. DOI: https://doi.org/10.1080/03050629.2016.1206391

\footnotetext{
${ }^{24}$ On this, see also Amorim Neto and Malamud (2019).
} 
Baldwin, Richard. 2011. "21st Century Regionalism: Filling the Gap between 21st Century Trade and 20th Century Trade Rules." WTO Staff Working Paper ERSD-2011-08. DOI: https://doi.org/10.2139/ ssrn. 1869845

Basco, Ana Inés. 2017. “Techno-Integration of Latin America: Institutions, Exponential Trade, and Equality in the Era of Algorithms." Technical Note IDB-TN-1340, INTAL-INT.

Bastiaens, Ida, and Evgeny Postnikov. 2017. "Greening Up: The Effects of Environmental Standards in EU and US Trade Agreements." Environmental Politics 26 (5): 847-869. DOI: https://doi.org/10.1080/0964401 6.2017.1338213

Bhagwati, Jagdwish. 1995. "US Trade Policy: The Infatuation with FTAs." Discussion Paper No. 726, Department of Economics, Columbia University.

Biadgleng, Ermias, and Jean-Christophe Maur. 2011. "The Influence of Preferential Trade Agreements on Implementation of Intellectual Property Rights in Developing Countries: A First Look." Issue Papers, ICTSD Programme on Innovation, Technology and Intellectual Property. DOI: https://doi.org/10.7215/ IP_IP_20111121

Blundell, R., and S. Bond. 1998. "Initial Conditions and Moment Restrictions in Dynamic Panel Data Models." Journal of Econometrics 87 (1): 115-143. DOI: https://doi.org/10.1016/S0304-4076(98)00009-8

Bown, Chad, Daniel Lederman, Samuel Pienknagura, and Raymond Robertson. 2017. Better Neighbors: Toward a Renewal of Economic Integration in Latin America. Washington, DC: World Bank Latin American and Caribbean Studies. DOI: https://doi.org/10.1596/978-1-4648-0977-4

Bruszt, Laszlo, and Nauro Campos. 2016. "Does Deep Economic Integration Increase State Capacity? Evidence from the 2004 European Union Enlargement and Beyond." Unpublished paper.

Büthe, Tim, and Helen Milner. 2008. "The Politics of Foreign Direct Investment into Developing Countries: Increasing FDI through International Trade Agreements?" American Journal of Political Science 52 (4): 741-762. DOI: https://doi.org/10.1111/j.1540-5907.2008.00340.x

Büthe, Tim, and Helen V. Milner. 2014. "Foreign Direct Investment and Institutional Diversity in Trade Agreements: Credibility, Commitment, and Economic Flows in the Developing World, 1971-2007." World Politics 66 (1): 88-122. DOI: https://doi.org/10.1017/S0043887113000336

Cárdenas, Mauricio. 2010. "State Capacity in Latin America." Economía 10 (2): 1-45. DOI: https://doi.org/ 10.1353/eco.2010.0003

Caves, Richard. 1996. Multinational Enterprise and Economic Analysis. Cambridge: Cambridge University Press.

Chauffour, Jean-Pierre, Anabel González, and Jean-Christophe Maur. 2011. "Preferential Trade Agreements: Implementation Matters" WTO Research and Analysis.

Chauffour, Jean-Pierre, and David Kleimann. 2012. "The Challenge of Implementing Preferential Trade Agreements in Developing Countries: Lessons for Rule Design." Society of International Economic Law, Third Biennial Global Conference. DOI: https://doi.org/10.2139/ssrn.2104183

Chayes, Abram, and Antonia Chayes. 1993. "On Compliance." International Organization 47 (2): 175-205. DOI: https://doi.org/10.1017/S0020818300027910

Cole, Wade. 2016. "Mind the Gap: State Capacity and the Implementation of Human Rights Treaties." International Organization 69 (2): 405-441. DOI: https://doi.org/10.1017/S002081831400040X

Devlin, Robert, and Ricardo Ffrench-Davis. 1998. "Towards an Evaluation of Regional Integration in Latin America in the 1990s."' Working Paper No. 2, INTAL ITD. DOI: https://doi.org/10.1111/1467-9701.00203

Dreher, Axel, Heiner Mikosch, and Stefan Voigt. 2015. "Membership Has Its Privileges: The Effect of Membership in International Organizations on FDI." World Development 66: 346-358. DOI: https://doi .org/10.1016/j.worlddev.2014.08.007

Estevadeordal, Antoni, and Kati Suominen. 2009. Bridging Regional Trade Agreements in the Americas. Washington, DC: Inter-American Development Bank.

Ethier, Wilfred. 2001. "The New Regionalism in the Americas: A Theoretical Framework." North American Journal of Economics and Finance 12 (2): 159-172. DOI: https://doi.org/10.1016/S1062-9408(01)00045-6

Feils, Dorothee, and Manzur Rahman. 2008. "Regional Economic Integration and Foreign Direct Investment: The Case of NAFTA." Management International Review 48 (2): 147-163. DOI: https://doi.org/10.1007/ s11575-008-0009-9

Goltermann, Lukas. 2012. "State Capacity and Compliance in ASEAN." In Roads to Regionalism: Genesis, Design, and Effects of Regional Organizations, edited by Tanja Börzel, Lukas Goltermann, Mathis Lohaus, and Kai Striebinger, 159-178. New York: Routledge. 
Gómez-Mera, Laura. 2013. Power and Regionalism in Latin America: The Politics of MERCOSUR. South Bend: University of Notre Dame Press. DOI: https://doi.org/10.2307/j.ctvpj7g3t

González, Anabel. 2009. “The Implementation of Preferential Trade Agreements: A Conceptual Note." InterAmerican Development Bank.

Granados, Jaime, and Rafael Cornejo. 2006. "Convergence in the Americas: Some Lessons from the DR-CAFTA Process." World Economy 29 (7): 857-891. DOI: https://doi.org/10.1111/j.1467-9701.2006.00827.x

Gray, Julia. 2014. "Domestic Capacity and the Implementation Gap in Regional Trade Agreements." Comparative Political Studies 47 (1): 55-84. DOI: https://doi.org/10.1177/0010414013488535

Guzman, Andrew. 2002. "A Compliance-Based Theory of International Law." California Law Review 90 (6): 1824-1888. DOI: https://doi.org/10.2307/3481436

Heidrich, Pablo, and Diana Tussie. 2009. "Regional Trade Agreements and the WTO: The Gyrating Gears of Interdependence." In Redesigning the World Trade Organization for the 21st Century, edited by Debra Steger, 417-436. Ottawa: Wilfrid Laurier University Press.

Hofmann, Claudia, Alberto Osnago, and Michele Ruta. 2018. "The Content of Preferential Trade Agreements." World Trade Review 18 (3): 365-398. DOI: https://doi.org/10.1017/S1474745618000071

Horn, Henrik, Petros Mavroidis, and Andre Sapir. 2010. "Beyond the WTO? An Anatomy of EU and US Preferential Trade Agreements." World Economy 33 (11): 1565-1588. DOI: https://doi.org/10.1111/ j.1467-9701.2010.01273.x

Jenne, Nicole, Luis Schenoni, and Francisco Urdinez. 2017. "Of Words and Deeds: Latin American Declaratory Regionalism, 1994-2014." Cambridge Review of International Affairs 30 (2-3): 195-215. DOI: https:// doi.org/10.1080/09557571.2017.1383358

Kaufmann, Daniel, Aart Kraay, and Massimo Mastruzzi. 2007. "The Worldwide Governance Indicators Project: Answering the Critics." World Bank Policy Research Working Paper; No. 4149. DOI: https://doi.org/ 10.1596/1813-9450-4149

Kaufmann, Daniel, Aart Kraay, and Massimo Mastruzzi. 2010. "The Worldwide Governance Indicators: Methodology and Analytical Issues." World Bank Policy Research Working Paper No. 5430.

Levy Yeyati, Eduardo, Ernesto Stein, and Christian Daude. 2003. "Regional Integration and the Location of FDI." Inter-American Development Bank Working Paper No. 492. DOI: https://doi.org/10.2139/ ssrn. 1818703

Luna, Juan Pablo, and Hillel Soifer. 2015. "Surveying State Capacity." Americas Barometer Insights, no. 119. http://www.vanderbilt.edu/lapop/insights/IO919en.pdf.

Mace, Gordon, Jean-Philippe Thérien, Diana Tussie, and Olivier Dabène. 2015. Summits and Regional Governance: The Americas in Comparative Perspective. London: Routledge. DOI: https://doi.org/10.4324/ 9781315736297

Malamud, Andrés, and Gian Luca Gardini. 2012. "Has Regionalism Peaked? The Latin American Quagmire and Its Lessons." International Spectator: Italian Journal of International Affairs 47 (1): 116-133. DOI: https://doi.org/10.1080/03932729.2012.655013

Mann, Michael. 1984. "The Autonomous Power of the State." European Journal of Sociology, 25 (2): 185-213. DOI: https://doi.org/10.1017/S0003975600004239

Markusen, James. 1984. "Multinationals, Multi-plant Economies, and the Gains from Trade." Journal of International Economics 16: 205-226. DOI: https://doi.org/10.1016/S0022-1996(84)80001-X

Medvedev, Denis. 2012. "Beyond Trade: The Impact of Preferential Trade Agreements on FDI Inflows." World Development 40 (1): 49-61. DOI: https://doi.org/10.1016/j.worlddev.2011.04.036

Ministerio de Comercio e Industrias. 2012. "Tratado de Promoción Comercial Panama y Estados Unidos de America." Documento Explicativo, Oficina de Negociaciones Comerciales Internacionales. https://www .mici.gob.pa/uploads/media_ficheros/2019/05/2/negociaciones-comerciales/tpc-panama-estadosunidos/documentos/documento-explicativo-tlc-panama-usa-comprimido.pdf.

Orefice, Gianluca, and Nadia Rocha. 2014. "Deep Integration and Production Networks: An Empirical Analysis." World Economy 37 (1):106-136. DOI: https://doi.org/10.1111/twec.12076

Osnago, Alberto, Nadia Rocha, and Michele Ruta. 2015. "Do Deep Trade Agreements Boost Vertical FDI?" World Bank Economic Review 30 (1): 119-125. DOI: https://doi.org/10.1596/32237

Riggirozzi, Pia. 2017. "The Social Turn and Contentious Politics in Latin American Post-Neoliberal Regionalism." In The Legitimacy of Regional Integration in Europe and the Americas, edited by Achim Hurrelmann and Steffen Schneider, 229-248. London: Palgrave Macmillan. DOI: https://doi.org/ 10.1057/9781137457004_13 
Rollo, Jim. 2007. "The Challenge of Negotiating RTAs for Developing Countries: What Could the WTO Do to Help?" Paper presented at the Conference on Multilateralising Regionalism, co-organized by the WTO, $\mathrm{HEI}$, and CEPR, Geneva, September.

Roodman, David. 2006. "How to Do xtabond2: An Introduction to 'Difference' and 'System' GMM in Stata." Center for Global Development Working Paper No. 103. DOI: https://doi.org/10.2139/ssrn.982943

Solís, Mireya, Barbara Stallings, and Saori N. Katada. 2009. Competitive Regionalism: FTA Diffusion in the Pacific Rim. New York: Palgrave Macmillan. DOI: https://doi.org/10.1057/9780230234239

Teorell, Jan, Stefan Dahlberg, Sören Holmberg, Bo Rothstein, Natalia A. Pachón, and Richard Svensson. 2018. "The Quality of Government Standard Dataset." University of Gothenburg, Sweden: Quality of Government Institute.

Toro, Jorge, Gloria Alonso, Pilar Esguerra, Daira Garrido, Ana María Iregui, Enrique Montes and Juan Mauricio Ramírez. 2006. "El impacto del Tratado de Libre Comercio con Estados Unidos en la balanza de pagos hasta 2010." Borradores de Economia No. 362, Banco de la República de Colombia.

UNCTAD. 2019. World Investment Report. Geneva: United Nations Publications.

Urdinez, Francisco, Camilo López-Burian, and Amancio de Oliveira. 2016. "MERCOSUR and the Brazilian Leadership Challenge in the Era of Chinese Growth: A Uruguayan Foreign Policy Perspective." New Global Studies 10 (1): 1-25. DOI: https://doi.org/10.1515/ngs-2015-0015

Vallejo, Hernán, and Camila Aguilar. 2002. "Economic Integration and the Attraction of Foreign Direct Investment: The Case of Latin America." Paper presented at the Seventh Annual Meeting of the Latin America and Caribbean Economic Association, Madrid, Spain, October.

Vernon, Raymond. 1971. Sovereignty at Bay: The Multinational Spread of U.S. Enterprises. New York: Basic Books. DOI: https://doi.org/10.1002/tie.5060130401

Villanueva, Brenda, and Lynel Polanco. 2010. "El DR-CAFTA y la inversion extranjera directa en la República Dominicana." USAID Report. https://pdf.usaid.gov/pdf_docs/PA00HPSS.pdf.

Viner, Jacob. 1950. The Customs Union Issue. New York: Carnegie Endowment for International Peace.

Walls, Helen, Richard Smith, and Peter Drahos. 2015. "Improving Regulatory Capacity to Manage Risks Associated with Trade Agreements." Globalization and Health 11 (14): 1-5. DOI: https://doi.org/10.1186/ s12992-015-0099-7

How to cite this article: Gómez-Mera, Laura, and Gonzalo Varela. 2021. Deep Trade Agreements and Domestic Institutions in the Americas. Latin American Research Review 56(3), pp. 607-624. DOl: https://doi.org/10.25222/ larr.679

Submitted: 23 July $2018 \quad$ Accepted: 25 November $2019 \quad$ Published: 07 September 2021

Copyright: (c) 2021 The Author(s). This is an open-access article distributed under the terms of the Creative Commons Attribution 4.0 International License (CC-BY 4.0), which permits unrestricted use, distribution, and reproduction in any medium, provided the original author and source are credited. See http://creativecommons.org/ licenses/by/4.0/. 